\title{
EDUCATIONAL PROTOCOL FOR PATIENTS ON ORAL ANTICOAGULANT THERAPY: CONSTRUCTION AND VALIDATION ${ }^{1}$
}

\author{
Flávia Martinelli Pelegrino², Fabiana Bolela ${ }^{3}$, Inaiara Scalçone de Almeida Corbi ${ }^{4}$, Ariana Rodrigues da Silva \\ Carvalho ${ }^{5}$, Rosana Aparecida Spadoti Dantas ${ }^{6}$
}

\footnotetext{
${ }^{1}$ Extract from the thesis - Evaluation of quality of life related to health, adhesion to drug treatment and self-efficscy of individuals submitted to an educational program after starting the use of an oral antocoagulant, submitted to the Program of Fundamental Nursing at the Escola de Enfermagem de Ribeirão Preto da Universidade de São Paulo, 2013.

${ }^{2}$ Ph.D. in Science. Nurse at the Ribeirão Preto Clinics Hospital. Ribeirão Preto, São Paulo, Brazil. E-mail: flavia-martinelli@bol. com.br

${ }^{3}$ Ph.D. in Science. Nurse at the Ribeirão Preto State Hospital. Ribeirão Preto, São Paulo. Brazil. E-mail: fbolela@yahoo.com.br

${ }^{4}$ Ph.D. in Science. Professor at Universidade Paulista. Araraquara, São Paulo, Brazil. E-mail: inaenf@yahoo.com.br

${ }^{5}$ Ph.D. in Science. Adjunct Professor at the Nursing Undergraduate Course of Universidade Estadual do Paraná, Cascavel, Paraná, Brazil. E-mail: arianacarvalho@outlook.com

${ }^{6}$ Associate Professor in Nursing. Associate Professor, Department of General and Specialized Escola de Enfermagem de Ribeirão Preto da Universidade de São Paulo. Ribeirão Preto, São Paulo, Brazil. E-mail: rsdantas@eerp.usp.br
}

\begin{abstract}
This is a report of experience on the construction and validation of an educational protocol for patients on oral anticoagulation therapy. Based on Bandura's Social Cognitive Theory, three phases were identified to construct the educational protocol. The literature review on oral anticoagulants was used to prepare the content of each phase of the protocol. As a result, verbal and written orientation in the phases of attention and retention were developed. In the reproduction and motivation phase, support through contact by telephone was provided. And finally, an improvement in the evaluation of the outcomes related to oral anticoagulant is expected in the performance phase. Once the educational protocol was defined, we proceeded with the face and content validity process, which allowed adaptations to the final version of the educational protocol constructed.
\end{abstract}

DESCRIPTORS: Anticoagulants. Health education. Protocols.

\section{PROTOCOLO EDUCATIVO PARA PACIENTES EM USO DE ANTICOAGULANTE ORAL: CONSTRUÇÃO E VALIDAÇÃO}

\begin{abstract}
RESUMO: Trata-se de um relato de experiência sobre a construção e validação de um protocolo educativo aos pacientes em uso de anticoagulante oral. Com base na Teoria Social Cognitiva de Bandura identificaram-se três fases necessárias para compor o protocolo educativo. O levantamento bibliográfico sobre anticoagulante oral auxiliou na elaboração do conteúdo de cada fase desse protocolo. Como resultado, tivemos na fase de atenção e retenção a elaboração da orientação verbal e escrita. Na fase de reprodução e motivação foi realizado um reforço por contato telefônico. Por último, na fase de desempenho espera-se melhoria na avaliação dos desfechos relacionados ao uso de anticoagulante oral. Definido o protocolo educativo, prosseguimos para validação de face e de conteúdo. Esse processo permitiu adequações na versão final do protocolo educativo construído.
\end{abstract}

DESCRITORES: Anticoagulantes. Educação em saúde. Protocolos.

\section{PROTOCOLO EDUCATIVO PARA PACIENTES EN USO DE ANTICOAGULANTE ORAL: CONSTRUCCIÓN Y VALIDACIÓN}

\begin{abstract}
RESUMEN: Se trata de un relato de experiencia sobre la construcción y validación de un protocolo educativo para pacientes en fase de uso de anticoagulación oral. Con base en la Teoría Cognitiva Social de Bandura se identificó tres fases necesarias para componer el protocolo educativo. La revisión de la literatura sobre anticoagulante oral ayudó a preparar el contenido de cada fase del protocolo. Como resultado, en la fase de la atención y retención se dio la elaboración de orientación verbal y escrita. En la fase de la reproducción y motivación fue realizado un refuerzo por contacto telefónico. Finalmente, en la fase de desempeño se espera la mejora en la evaluación de los resultados relacionados al uso de anticoagulante oral. Definido el protocolo educativo se dio la validación de la cara y el contenido. Este proceso permitió adaptaciones que permitieron la finalización de la construcción del protocolo educativo.
\end{abstract}

DESCRIPTORES: Anticoagulantes. Educación en salud. Protocolos. 


\section{INTRODUCTION}

Oral anticoagulant therapy (OAT) comprises vitamin $\mathrm{k}$ antagonist drugs, which act by increasing the blood clotting time of the individual (assessed by the INR - International Normalized Ratio). They are generally prescribed in the presence of diseases that lead to the formation of intravascular thrombi, such as the presence of venous thrombosis, stroke or cardiac arrhythmia. Their use requires constant and strict control of blood levels so that the patient benefits from safe treatment. Patients who start using OAT remain hospitalized until the dose adjustment to their clinical condition, and, even after discharge, frequent tracking is needed to monitor the treatment. ${ }^{1}$

Numerous factors influence blood coagulation and may lead the patient to a higher risk of bleeding or thrombi. These factors are related to individual aspects (e.g., genetic influence and comorbidities), food (e.g., excessive intake of foods rich in vitamin $\mathrm{K}$ ) and use of other drugs (e.g., anti-inflammatories). ${ }^{2}$ To minimize the risk of complications due to OAT use, specialized clinics in the management of such treatment have become common on the world stage. Specialized health professionals (physicians, pharmacists, nurses) develop actions for the realization of educational programs with verbal and written guidance, and the use of instructional videos; ${ }^{3-6}$ support groups, home visits, followup by telephone and quality indicators for the service provided. ${ }^{7}$

Studies suggest that patient education promotes better clinical outcomes, such as greater compliance, better INR control with values within the expected therapeutic range, ${ }^{8}$ better understanding of the signs and symptoms of complications, ${ }^{9-10}$ significant reduction in readmissions ${ }^{11-12}$ and decreased health costs. ${ }^{13}$ Such an education process should begin even during the patient's hospitalization and continue throughout the outpatient follow-up of the patient. ${ }^{14}$ This practice also supports greater involvement of professionals working with this population. ${ }^{15}$

In this paper, we report the experience of building an educational protocol for the self-care of patients using OAT, and carrying out the face and content validity by a board of experts.

\section{BUILDING THE EDUCATIONAL PRO- TOCOL}

The construction of the protocol is one of the development stages of two randomized clinical trials in progress, aiming to test whether participation in the educational program, focused on the self-care of patients using OAT, improves the impact of treatment on the quality of life and satisfaction with the drug product. Both studies, which included the construction stage of the educational protocol, were performed in a public hospital in the state of São Paulo, after approval by the Research Ethics Committee responsible for the hospital referred to.

\section{Theoretical foundation}

An American study is an example in which proposing changes to human behavior in health care is a challenge. This study, researching the various existing theories on human behavior, defined five stages in the change process: 1) gaining attention, 2) having stimulating material, 3) identifying performance and providing feedback, 4) providing guidance for learning and 5) increasing retention and transfer. However, this process involves numerous factors (the individual, the health system, the geographic, social and political environment) that interact in complex ways to influence the behavior in question. ${ }^{16}$

Another scholar ${ }^{17}$ in the area adds that the behavior comes from the perspective of the human agency for self-development, adaptation and change. Being an agent means influencing the function itself and the circumstances of life intentionally, in other words, it is mediated by a self-awareness that enables them to adopt personal standards, monitor their actions to reflections on their personal effectiveness, making adjustments whenever necessary. ${ }^{17}$ The Social Cognitive Theory of the Personality may be called the Social Cognitive Theory or simply Bandura's Theory. It assumes that human functioning is associated with a wide network of influences mediated by cognitive processes in the adaptation to human changes. As if thoughts and actions were products of a dynamic interplay between personal, behavioral and environmental influences, enabling therapeutic interventions. ${ }^{17}$

In short, "that which people think, believe and feel affects how they behave". ${ }^{17: 99}$ These 
capabilities provide a cognitive means to these individuals. Perhaps, among these cognitive aspects, the belief in self-efficacy is what most affects human functioning. Self-efficacy is a "judgment of people in their capabilities to organize and execute actions required to achieve certain performance" ${ }^{17: 101}$ These beliefs provide the foundation for human motivation, for well-being and for social achievements.

The assumption of this theory helps us to understand why people's behaviors are sometimes not related to their actual capabilities and why they differ from each other, even if they have similar knowledge and skills. Thus, we elected this theory to build the educational protocol.

\section{Definition of the protocol}

In an attempt to combine the theoretical precepts to the construction of an educational protocol for OAT patients, we adapted Table 1 from the book "The Nurse as Educator: Principles of Teaching and Learning for Nursing Practice" 18 , which represents the foundation of Bandura's theory.

Table 1 - Processing of information according to Bandura's Theoretical Model of Social Learning adapted to patients who will use $\mathrm{OAT}^{18: 91}$

\begin{tabular}{|c|c|c|c|c|}
\hline $\begin{array}{l}\text { External } \\
\text { processes }\end{array}$ & \multicolumn{3}{|c|}{ Internal processes } & External processes \\
\hline & \multicolumn{3}{|c|}{ Self-Regulation and Control } & \\
\hline & Attention & Retention & $\rightarrow$ Reproduction $\rightarrow$ Motivation & Performance \\
\hline $\begin{array}{l}\text { Oral anticoagu- } \\
\text { lant use }\end{array}$ & $\begin{array}{l}\text { Presentation } \\
\text { about the treat- } \\
\text { ment: } \\
\text {-verbal (slides) } \\
\text {-written (leaflet) }\end{array}$ & $\begin{array}{l}\text { The use of figures } \\
\text { and texts with a fo- } \\
\text { cus on the guidance } \\
\text { provided, aimed } \\
\text { at the patient's } \\
\text { memorizing of the } \\
\text { content. }\end{array}$ & $\begin{array}{l}\text { Reinforcement by telephone } \\
\text { contact: } \\
\text { - } 1 \text { week and } 1 \text { month after dis- } \\
\text { charge } \\
\text { Verbalization of the content } \\
\text { learned by the patient faced with } \\
\text { the nurse's questions. }\end{array}$ & $\begin{array}{l}\text { Better clinical out- } \\
\text { comes, adherence and } \\
\text { treatment satisfaction, } \\
\text { decreased emotional } \\
\text { impact. }\end{array}$ \\
\hline
\end{tabular}

Table 1 shows that, initially, the attention phase takes place, a condition necessary for any learning to happen. Next, there is the retentive phase, which involves the storage and retrieval of what has been observed. The reproduction phase is in third place, wherein the mental training and corrective feedback strengthen the reproduction of the behavior. Finally, there is the motivation stage, in which the learner is motivated to perform a certain type of behavior. ${ }^{18}$

One of the foundations of this theory that stands out is the vicarious reinforcement. A person can acquire skills from a certain behavior, but learning will rarely be activated if it is received in a negative or unfavorable manner. When they go through experiences of reinforcement, individuals observe the progression they are making and tend to set goals of progressive improvement for themselves. ${ }^{17}$ Hence, the learning situation and the appropriateness of subsequent situations will make the behavior become adopted.

\section{Verbal and written guidance (attention and retention phase)}

For the preparation of the content to compose the verbal (slides) and writing (pamphlet) guidance, a bibliographical survey of studies relevant to the themes of oral anticoagulation and Bandura's Theory was conducted. The databases used were: the Medical Literature Analysis and Retrieval System Online (MEDLINE) and the Latin American and Caribbean Literature on Health Sciences (LILACS).

Of the studies on OAT, ${ }^{4-5,9,19-23}$ two studies stood out. One of them on the systematic review of OAT education strategies ${ }^{9}$ and another methodological study of building an instrument of knowledge about OAT. ${ }^{19}$

The main information brought by these authors relates to: 1) physiological aspects of the drug, such as mechanisms of action; 2) risk-benefit in indicating this treatment with a view to safe treatment; 3) adherence to schedule, dose and 
failure in intake; 4) balanced diet rich in vitamin $\mathrm{K}$ and fatty foods; 5) strict laboratory monitoring; 6) the science of drug interactions; 7) the need for self-care; 8) alert for surgeries, dental care, pregnancy and travel; 9) specialized health professionals; and 10) guidance on the need for the emergency service.

There are still few studies on the behavior of individuals who make use of OAT considering Bandura's Theory. However, studies that applied this theory in other populations ${ }^{24-27}$ assisted in the analysis of the educational strategies used. We have the use of leaflets and telephone contact to reinforce the behavior of patients to maintain control of blood pressure. ${ }^{24}$ In Korea, psychiatric patients were helped to cope with treatment through videos of vicarious experiences, group discussions and follow-up by telephone. ${ }^{25}$ Tele- phone contact was also the reinforcement method adopted by American nurses for the modification of risk factors in patients with acute myocardial infarction. ${ }^{26}$ Internet use was another feature used to enhance the behavior of mothers in maintaining breastfeeding. ${ }^{27}$

A presentation for verbal guidance was developed in 26 slides from the PowerPoint ${ }^{\circledR}$ for Windows program, 2007 version, containing illustrations to address topics related to the use of OAT (Table 2). The use of figures allows the researcher to retain the attention and stimulate the participant to report their experiences as the information is given. For example, the figure of the normal blood vessel and its occlusion due to thrombus illustrates the action of the OAT. Written guidance was given with the delivery of an information leaflet on treatment with OAT.

Table 2 - Topics addressed for teaching patients about oral anticoagulation

\begin{tabular}{|l|l|}
\hline \multicolumn{1}{|c|}{ Topics } & \multicolumn{1}{c|}{ Description } \\
\hline Physiology & Definition of oral anticoagulants, mechanisms of action and clinical indication. \\
\hline Medication & Dose, schedule, storage and duration of treatment. \\
\hline Monitoring of anticoagulation & $\begin{array}{l}\text { Meaning of INR and normal value expected for each indication, collection pe- } \\
\text { riod and consultations. }\end{array}$ \\
\hline Using other drugs & Interaction with allopathic medicines and those considered "natural". \\
\hline Meals & Intake of foods rich in vitamin K and fats. \\
\hline Alcoholic beverages & Avoid drinking alcohol, if it occurs, do not stop taking the oral anticoagulant. \\
\hline Pregnancy & Need to start oral anticoagulant for injection. \\
\hline Activities & In physical, domestic or labor activities use protective measures. \\
\hline Health care & $\begin{array}{l}\text { Alert about oral anticoagulant to another professional and take the INR value } \\
\text { card. }\end{array}$ \\
\hline Traveling & $\begin{array}{l}\text { Take the oral anticoagulant and plan to perform the INR outside of your health- } \\
\text { care facility. }\end{array}$ \\
\hline $\begin{array}{l}\text { Signs and symptoms of complica- } \\
\text { tions related to treatment with } \\
\text { oral anticoagulant }\end{array}$ & $\begin{array}{l}\text { Information on the possibility of complications related to underdosing (throm- } \\
\text { bus formation) and overdose (bleeding), as well as the need to seek health care } \\
\text { in cases such as: bleeding in the gums, in the urine, among others. }\end{array}$ \\
\hline
\end{tabular}

\section{Telephone reinforcement (reproduction and motivation phase)}

Resuming the precept of Bandura's Theory, ${ }^{17}$ individuals may or may not choose to perform the behavior about which they learned. This decision is determined by the consequences that such action may cause. The use of positive reinforcement and encouragement is important for that individual's decision making.
In our study, reinforcement for OAT patients was done using telephone contact. At this time, the nurse/researcher performed the positive stimulus for the participant so that they could recall the relevant information on the use of the OAT, encouraging them positively. For the telephone contact, a script was used, which was developed by the researchers and composed of questions and conducts guided by the theoretical framework and the bibliographical survey conducted for this study (Table 3). 


\section{Table 3 - Script for telephone contact}

\begin{tabular}{|c|c|c|}
\hline \multicolumn{3}{|c|}{$\begin{array}{l}\text { Presentation: "I'm the nurse who spoke with Mr.(Mrs.) on the use of oral anticoagulants during your hospital- } \\
\text { ization". }\end{array}$} \\
\hline Questions & Answers & Conduct \\
\hline $\begin{array}{l}\text { 1) After being discharged from } \\
\text { the hospital, did you feel able } \\
\text { to carry out the guidance given } \\
\text { during their hospitalization? }\end{array}$ & $\begin{array}{l}\text { ( ) yes } \\
\text { ( ) no }\end{array}$ & $\begin{array}{l}\text { If yes: positive stimulus ("very good, now let's remember some } \\
\text { important information"). } \\
\text { If no: positive reinforcement ("okay then, now let's remember } \\
\text { some important information"). }\end{array}$ \\
\hline $\begin{array}{l}\text { 2) Are you having difficulties } \\
\text { taking the oral anticoagulant as } \\
\text { per guidance during discharge? }\end{array}$ & $\begin{array}{l}\text { ( ) yes } \\
\text { ( ) no }\end{array}$ & $\begin{array}{l}\text { If yes: inquire about the difficulty and then guide them how } \\
\text { to properly take oral anticoagulants, according to medical } \\
\text { prescription. } \\
\text { If no: positive stimulus ("very good"). }\end{array}$ \\
\hline $\begin{array}{l}\text { 3) Do you remember what you } \\
\text { should do/how you should act } \\
\text { when realizing that you have } \\
\text { forgotten to take your medi- } \\
\text { cine? }\end{array}$ & $\begin{array}{l}\text { ( ) yes } \\
\text { ( ) no }\end{array}$ & $\begin{array}{l}\text { If yes: if remembered on the same day, take the medicine right } \\
\text { away at the prescribed dose. If remembered only the next day, } \\
\text { do not take the dose from the previous day, only the dose for } \\
\text { that day ("very good"). } \\
\text { If no: guide them according to the expected response. }\end{array}$ \\
\hline $\begin{array}{l}\text { 4) If you experience any dis- } \\
\text { ease, for example, flu or infec- } \\
\text { tion, can you tell me what kind } \\
\text { of care you should have? }\end{array}$ & $\begin{array}{l}\text { ( ) yes } \\
\text { ( ) no }\end{array}$ & $\begin{array}{l}\text { If yes: do not take any medication without medical advice } \\
\text { ("very good"). } \\
\text { If no: remind them about the medications that should be taken } \\
\text { with caution (e.g., antibiotics, analgesics, anti-inflammatories } \\
\text { and medicinal herbs). }\end{array}$ \\
\hline $\begin{array}{l}\text { 5) Another caution is about } \\
\text { food, can you tell me with } \\
\text { which foods this caution should } \\
\text { be taken? }\end{array}$ & $\begin{array}{l}\text { ( ) yes } \\
\text { ( ) no }\end{array}$ & $\begin{array}{l}\text { If yes: caution with foods rich in fat, dark leafy greens, beets, } \\
\text { etc. ("very good"). } \\
\text { If no: remind them about diet and ask questions about other } \\
\text { foods. }\end{array}$ \\
\hline $\begin{array}{l}\text { 6) If you go to the dentist or an- } \\
\text { other doctor, what is important } \\
\text { to remind them? }\end{array}$ & $\begin{array}{l}\text { ( ) yes } \\
\text { ( ) no }\end{array}$ & $\begin{array}{l}\text { If yes: making use of oral anticoagulants ("very good"). } \\
\text { If no: remind them about the importance of such information. } \\
\text { If they are women of childbearing age, reinforce the impor- } \\
\text { tance of going to the gynecologist especially in the 1st trimester } \\
\text { to alter the oral anticoagulant to the injectable type. }\end{array}$ \\
\hline $\begin{array}{l}\text { 7) If you travel, what kind of } \\
\text { care should you take? }\end{array}$ & $\begin{array}{l}\text { ( ) yes } \\
\text { ( ) no }\end{array}$ & $\begin{array}{l}\text { If yes: you need to take an oral anticoagulant for every day of } \\
\text { the trip ("very good"). } \\
\text { If no: remind them about the importance of such information. }\end{array}$ \\
\hline $\begin{array}{l}\text { 8) So, it is important to take the } \\
\text { oral anticoagulant correctly. } \\
\text { Can you tell me, how you are } \\
\text { currently taking oral anticoagu- } \\
\text { lants this week? }\end{array}$ & $\begin{array}{l}\text { ( ) yes } \\
\text { ( ) no }\end{array}$ & $\begin{array}{l}\text { If yes: Monday ( ); Tuesday ( ); Wednesday ( ); Thursday ( ); } \\
\text { Friday ( ); Saturday ( ) and Sunday ( ) ("very good"). } \\
\text { If no: remind them about the importance of this information } \\
\text { and if the participant reports another dose, ask about the rea- } \\
\text { son for this change. }\end{array}$ \\
\hline $\begin{array}{l}\text { 9) If the anticoagulant dose } \\
\text { is inadequate, can you recall } \\
\text { what signs/symptoms you may } \\
\text { present? }\end{array}$ & $\begin{array}{l}\text { ( ) yes } \\
\text { ( ) no }\end{array}$ & $\begin{array}{l}\text { If yes: bleeding gums, blood in urine, cuts that does not stop } \\
\text { bleeding, dark or red stools, purple spots, severe headache, leg } \\
\text { pain, swelling, throbbing, dizziness, malaise. } \\
\text { If no: remind them about the signs and symptoms of treatment } \\
\text { complications and emphasize the importance of their observa- } \\
\text { tions. }\end{array}$ \\
\hline $\begin{array}{l}\text { 10) If they have any of these } \\
\text { signs/symptoms, it is necessary } \\
\text { to seek a health service and } \\
\text { remember the INR value. Can } \\
\text { you tell me what this value was } \\
\text { on your last visit? }\end{array}$ & $\begin{array}{l}\text { ( ) yes } \\
\text { ( ) no }\end{array}$ & $\begin{array}{l}\text { If yes: value ( ) ("very good"). } \\
\text { If no: remind them about the importance of this information } \\
\text { and if the participant reports another INR value, ask whether } \\
\text { there was the need to perform the examination at another } \\
\text { health service. }\end{array}$ \\
\hline $\begin{array}{l}\text { Closure: Would you like to ask } \\
\text { me anything? Would you like } \\
\text { me to pass some of this infor- } \\
\text { mation on to your family? }\end{array}$ & $\begin{array}{l}\text { ( ) yes } \\
\text { ( ) no }\end{array}$ & $\begin{array}{l}\text { If yes: name of the family member ( ). } \\
\text { If no: thanks for your time. }\end{array}$ \\
\hline
\end{tabular}




\section{VALIDATION OF THE EDUCATIONAL PROTOCOL}

The face and content validity of the material (slides and leaflet) designed for the educational protocol was performed by a board of experts composed of a multidisciplinary team of two nurses, a physician, a nutritionist, a psychologist, two pharmacists, a social worker and a patient using OAT. Professionals worked in the hospital where the study was conducted and they were elected to contribute with their practical experience. The patient was male and used OAT, due to atrial fibrillation, for four years. In a meeting held between researchers and the staff, the material (slides and leaflet) was submitted to face and content assessment. Suggestions were made for the addition of a suitable place for the storage of the OAT, replacement of words to facilitate the understanding of the patients and reformulating some information so that it was objective and so the terms stood out to refer to the key information on each slide.

The script for telephone contact was subjected to face and content validity by five research nurses, elected for their knowledge regarding Ban- dura's Theory. Suggestions were made for the reformulation of sentences using verbs that address stimulus to action. For instance, "if you forget to take the anticoagulant, would you remember what to do?". All suggestions were accepted and incorporated into the material.

Next, in order to implement the educational protocol, the researchers conducted interviews with patients admitted to the hospital for a month. A convenience sample was composed of seven patients using OAT. After verbal and written guidance, participants were asked about the need for changes in the material constructed for the educational protocol. Four of the participants considered the presentation of long slides, and the adjustments made, the presentation time was reduced from 45 to 30 minutes. The script for telephone contact was also evaluated by the participants and the application time of 15 minutes was considered adequate.

\section{Expected results (performance phase)}

Provided with the material defined for the educational protocol to patients using OAT, figure 1 outlines the proposed implementation.

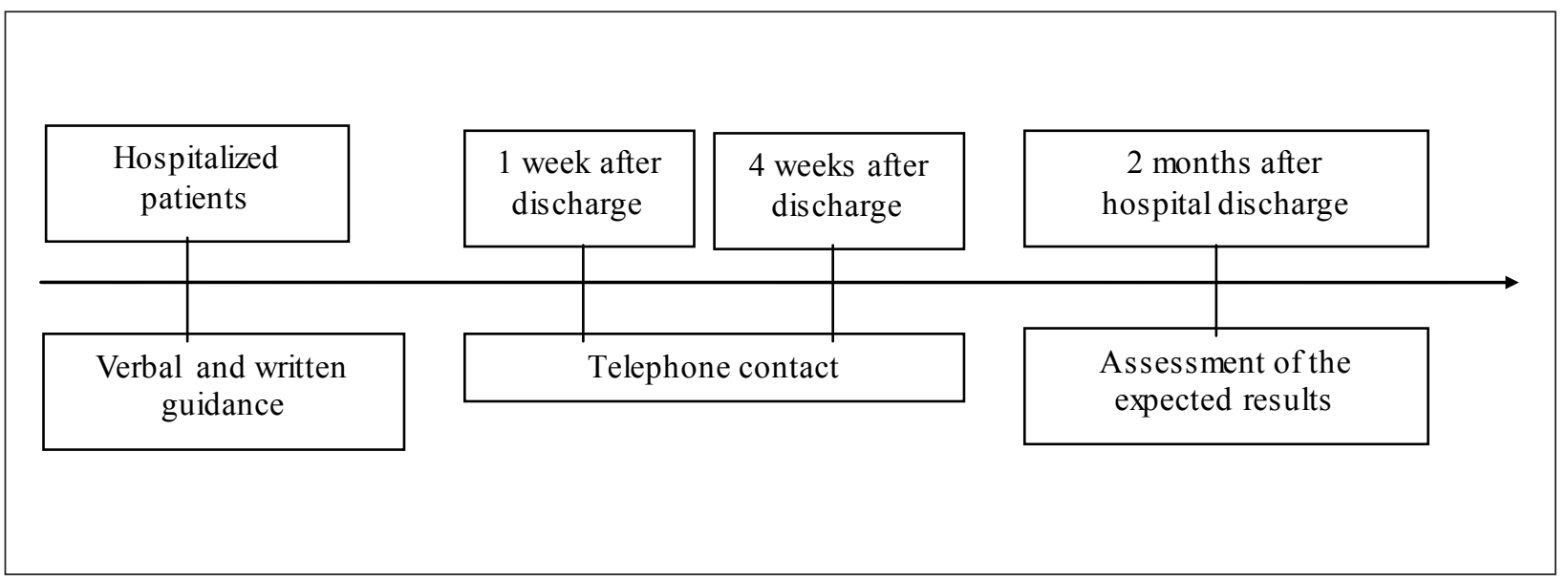

Figure 1 - Educational protocol according to the follow-up time

When the patient starts using the OAT, they remain hospitalized for a period until the OAT dose is adjusted. It is during this period that the nurse will approach the OAT patient with a laptop and perform the verbal guidance and deliver the information leaflet. After discharge from the hospital, we propose conducting a follow-up telephone call during the first and fourth week. The definition of this period is based on the feature of adjusting the OAT. It is necessary to perform weekly blood tests at the start of the OAT. After adjusting the OAT dose, blood tests may be performed monthly.

Determining the period for assessing the expected results, i.e., the performance of the patient when participating in an educational intervention focused on self-care with the OAT will be linked to the reality of each health service. ${ }^{28-30}$ As regards our reality, it was suggested that this review was conducted two months after the participant's discharge. 
Thus, it is expected that with the use of an educational protocol, the knowledge and motivation for the self-care of patients using OAT would result in better control of blood clotting, better quality of life, greater treatment adherence and decreased emotional impact on them. The assessment of such outcomes can be performed with instruments and/or validated questionnaires, which already exist in literature..$^{31-33}$

\section{FINAL CONSIDERATIONS}

Protocols to guide the conduct of health professionals in search of better results related to various treatments have been developed and successfully applied in different contexts. Therefore, it is essential to know the reality of the target population that the development and implementation of a protocol will be dedicated to.

In our reality, OAT patients are mostly elderly people who have difficulty reading and understanding. Considering these aspects was the basis for directing the researchers in choosing the best strategies to prioritize the educational content.

This experience proved important for us to identify that the potential for the use of this protocol is related to the use of resources accessible to health services, facilitating their implementation and reflecting the best care for patients using OAT. The motivation, availability and knowledge of health professionals in using this protocol may be some of the barriers to their effective implementation in daily practice.

Even in the face of obstacles, we suggest that the implementation of the educational protocol be carried out and, in the long term, we should consider possibilities for application in larger groups of patients, different cultures and in public and private health institutions.

When we decided to report the experience of constructing and validating an educational protocol, we also collaborated to point out the difficulties involved in this task. We observed that the patient's emotional state is an ambiguous factor, which may be both limiting and impulsive, by providing patient involvement in the explanations of the researchers on the disease and its treatment. Even with the health terminology adjustments to the content of the educational protocol, the cognitive status of some patients makes them more susceptible to longer explanations. Finally, the very fact of change - starting to use oral anticoagulants - imposes the decision of a behavior on a patient, which may be expected or not. Intervention studies conducted by the authors are being concluded and will confirm that the use of this educational protocol with incentives by telephone has helped patients in the adherence to treatment with oral anticoagulants.

\section{REFERENCES}

1. Ichimura $Y$, Takahashi H, Lee MT, Shiomi M, Mihara $\mathrm{K}$, Morita $\mathrm{T}$, et al. Inter-individual differences in baseline coagulation activities and their implications for international normalized ratio control during warfarin initiation Therapy. Clin Pharmacokinet. 2012; 1(4):130-6.

2. Christensen TD, Johnsen SP, Hjortdal VE, Hasenkam JM. Self-management of oral anticoagulant therapy: a systematic review and meta-analysis. Int J Cardiol. 2007; 118(1):54-61.

3. Wittkowsky AK, Nutescu EA, Blackburn J, Mullins J, Hardman J, Mitchell J, et al. Outcomes of oral anticoagulant therapy managed by telephone vs in-office visits in an anticoagulation clinic setting. CHEST. 2006, 130: 1385-9.

4. Hua TD, Vormfelde SV, Abed MA, Schneider-Rudt H, Sobotta P, Friede T, et al. Practice nursed-based, individual and videoassisted patient education in oral anticoagulation-Protocol of a clusterrandomized controlled trial. BMC Family Practice. 2011; 1(12):1-17.

5. Stafford L, Peterson GM, Bereznicki LRE, Jackson SL. A role for pharmacists in community-based postdischarge warfarin management: protocol for the 'the role of community pharmacy in post hospital management of patients initiated on warfarin' study. BMC Health Serv Res. 2011, 11(16):1-11.

6. Tang EO, Lai CS, Lee KK, Wong RS, Cheng G, Chan TY: Relationship between patients' warfarin knowledge and anticoagulation control. Ann Pharmacother. 2003; 37(1):34-9.

7. Poller L. Application of the UK NHS Improvement anticoagulation commissioning support document for 'safety indicators' in atrial fibrillation. Results of the European Action on Anticoagulation study. J Clin Pathol. 2012, 65(1):452-6.

8. Khan TI, Kamali F, Kesteven P, Avery P, Wynne $H$. The value of education and self-monitoring in the management of warfarin therapy in older patients with unstable control of anticoagulation. Br J Haematol. 2004 Aug; 126(4):557-64.

9. Wofford JL, Wells MD, Singh S. Best strategies for patient education about anticoagulation with warfarin: a systematic review. BMC Health Serv Res. 2008; 8(40): 1-8.

10. Kagansky N, Knobler H, Rimon E, Ozer Z, Levy S. Safety of anticoagulation therapy in well-informed older patients. Arch Intern Med. 2004; 164(1):204450 . 
11. Pernod G, Labarère J, Yver J, Satger B, Allenet B, Berremili T, et al. EDUC'AVK: Reduction of oral anticoagulant-related adverse events after patient education: a prospective multicenter open randomized study. J Gen Intern Med. 2008; 23(9):1441-6.

12. Geyer A, Ford MA, Rindone JP. The use of letter communication for patients enrolled in a pharmacist managed anticoagulation clinic. J Clin Pharmacy and Therapeutics. 2011; 23(3): 553-6.

13. Grunau BE, Wiens MO, Harder KK. Patient self-management of warfarin therapy Pragmatic feasibility study in Canadian primary care. Can Fam Physician. 2011; 57(1):e292-8.

14. Pennsylvania Patient Safety Advisory. anticoagulation management service: safer care, maximizing outcomes. Patient Saf Advis. 2008; 5(3):81-4.

15. Rigon AG, Neves ET. Educação em saúde e a atuação de enfermagem no contexto de unidades de internação hospitalar: o que tem sido ou há para ser dito? Texto Contexto Enferm. 2011 Out-Dez; 20(4): 812-7.

16. Kinzie MB. Instructional design strategies for health behavior change. Patient Educ Couns. 2005 Jan;56(1):3-15.

17. Bandura A, Azzi RG, Polydoro S. Teoria social cognitiva: conceitos básicos. Porto Alegre (RS): ArtMed, 2008.

18. Bastable SB. O enfermeiro como educador: princípios de ensino-aprendizagem para a prática de enfermagem. Porto Alegre (RS): ArtMed, 2010.

19. Briggs AM, Jackson TR, Bruce S, Shapiro NL. The development and performance validation of a tool to assess patient anticoagulation knowledge. Res Social Adm Pharm. 2005; 1(1):40-59.

20. Newall F, Monagle P, Johnston L. Patient understanding of warfarin therapy: a review of education strategies. Hematology. 2005; 10(6):437-42.

21. Eickhoff JS, Wangen TM, Notch KB, Ferguson TJ, Nickel TW, Schafer AR, et al. Creating an anticoagulant patient education class. J Vasc Nurs. 2010; 28(4):132-5.

22. Field TS, Tjia J, Mazor KM, Donovan JL, Kanaan AO, Harrold LR, et al. Randomized trial of a warfarin communication protocol for nursing homes: an SBAR -based Approach. Am J Med. 2011; 124(2):179.e1-7.
23. Seliverstov I. Practical management approaches to anticoagulation non-compliance, health literacy, and limited English proficiency in the outpatient clinic setting. J Thromb Thrombolysis. 2011 Apr;31(3):3215.

24. Rudd P, Miller NH, Kaufman J, Kraemer HC, Bandura A, Greenwald G, et al. Nurse management for hypertension a systems approach. AJH. 2004; 17(10):921-7.

25. Shon HK. The effects of medication and symptom management education program based on selfefficacy theory for the psychiatric patients. Taehan Kanho Hakhoe Chi. 2003 Dec; 33(8):1145-52.

26. DeBusk RF, Miller NH, Superko HR, Dennis CA, Thomas RJ, Lew HT, et al. A case-management system for coronary risk factor modification after acute myocardial infarction. Ann Intern Med. 1994; 120(9):721-9.

27. Ahmed A, Ouzzani M. Development and assessment of an interactive web-based breastfeeding monitoring system (LACTOR). Matern Child Health J [online]. 2013 Jul; [citado 2013 dez 22]; [aprox.7 telas]. Disponível em DOI: 10.1007/s10995-012-1074-z.

28. Bauer KA. Duration of anticoagulation: applying the guidelines and beyond: Hematology Am Soc Hematol Educ Program. 2010; 2010:210-5.

29. Terra-Filho M, Menna-Barreto SS. Recomendações para o manejo da tromboembolia pulmonar, 2009. J Bras Pneumol. 2010; 36(supl.1):S1-68.

30. Jong PA, Coppens M, Middeldorp S. Duration of anticoagulant therapy for venous thromboembolism: balancing benefits and harms on the long term. Br J Haematol. 2012 Aug;158(4):433-41.

31. Zigmond AS, Snaith RP. The hospital anxiety and depression scale. Acta Psychiat. Scand. 1983; 67(1):361-70.

32. Pelegrino FM, Cross-cultural adaptation and psychometric properties of the Brazilian-Portuguese version of the Duke Anticoagulation Satisfaction Scale. J Clin Nurs. 2012 Sep;21(17-18):2509-17.

33. Carvalho ARS, Dantas RAS, Pelegrino FM, Corbi ISA. Adaptação e validação de uma medida de adesão à terapia de anticoagulação oral. Rev LatinoAm Enfermagem. 2010; 18(3):1-8. 